\title{
OBESITY: ANOTHER HAZARD FOR SPINA BIFIDA CHILDREN
}

\author{
M. C. HAYES-ALLEN AND F. C. TRING \\ Department of Human Biology and Anatomy, The University, Sheffield S10 2TN
}

In spite of the almost universal prevalence of obesity in affluent societies there is still no satisfactory and fully comprehensive definition of a disease which continues to be the most common nutritional disturbance (Sedgwick, 1971). The problem has led to recent concern about the observed alteration over the past few decades of the distribution of weight for height in both adults and children (Newens and Goldstein, 1972), but, however computed, the high incidence of obesity has been confirmed. A significant estimate has emphasized the extent of the problem (Brit. med. J., 1970), suggesting that at least $3 \%$ of British school children are affected by obesity, highlighting the continuing problem of infantile obesity and overnutrition even though the disease is recognized to be, in most cases, an avoidable one.

Clinicians now accept that dietary advice should be given for those children whose weight is between 10 and $20 \%$ above that expected for their age and height (Eid, 1970). However, Illingworth (1968) suggests that prevention of obesity may have to start in early infancy in order to prevent chronicity. Once established, obesity shows a marked tendency to become a self-perpetuating condition, persisting from childhood into adolescence and young adult life (Lloyd, Wolff, and Whelan, 1961). Early detection of obesity is therefore important not only because of its close association with other health hazards (Hooper and Alexander, 1971) but because obesity is also likely to complicate still further any existing chronic illness and disability (Tracey, De, and Harper, 1971).

Lorber (1969) has remarked upon the apparent obesity of children with spina bifida, but in this group of children the true extent of obesity can be easily overlooked if conventional means of measurement are used (Hayes-Allen, 1972). If obesity is present among these severely disabled children it is an unnecessary additional handicap which is largely avoidable if it is detected early.

This paper reports on a continuing survey of children with spina bifida, describes the assessment of obesity among this group, and discusses its significance.

\section{Materials AND Methods}

\section{The SAMPLe}

The 50 children, 23 boys and 27 girls, studied in this investigation were the entire child population of Mossbrook School, the City of Sheffield's residential school for children with spina bifida (myelomeningocele). Their ages ranged from 4 to 15 years. All the data presented here were collected in the summer and autumn of 1972.

\section{ASSESSMENT OF OBESITY}

Conventional techniques involving immersion in water were thought to be too difficult to use with partially paralysed children. On the assumption that body density is related to percentage fat in the same way as in adults, Paŕizkova (1961) has shown that a reasonable prediction can be obtained from two skinfold measurements, e.g., triceps and biceps. Parnell (1958) used the sum of three skinfold measurements (triceps, subscapular, and suprailiac) to deduce a fat score in his system of somatotyping. However, on examining our unique sample it was clear that lower limb fat should also be included in the estimation of body fat. Pařizkova and Bůžková (1971) have recently produced a nomogram for prediction of body fat from the sum of the various skinfolds. The best prediction is available from the sum of five skinfold measurements (triceps, subscapular, suprailiac, biceps, and calf). Addition of further skinfolds did not apparently improve predictive values.

\section{Skinfold Sites}

In this investigation we have measured triceps, subscapular, suprailiac, biceps, calf, and thigh skinfolds to determine percentage fat. All the measurements were made on the left side of each child. The results of these six measurements are presented in Table I. The procedure for site determination was the same as that recommended by the International Biological Programme Handbook (Tanner, Hiernaux, and Jarman, 1969) except that because nearly all the children were unable to stand 
TABLE I

DISTRIBUTION OF SKINFOLD

\begin{tabular}{|c|c|c|c|c|c|c|}
\hline & & \multicolumn{2}{|c|}{ Boys } & \multicolumn{2}{|c|}{ Girls } & \multirow[b]{2}{*}{ All } \\
\hline & & Under $10 \mathrm{yr}$ & Over $10 \mathrm{yr}$ & Under 10 yr & Over $10 \mathrm{yr}$ & \\
\hline Number & & 13 & 10 & 16 & 11 & 50 \\
\hline $\begin{array}{l}\text { Triceps (mm) } \\
\text { Under 10.1 } \\
10 \cdot 1-20 \cdot 0 \ldots \\
20 \cdot 1-30 \cdot 0 \\
\text { Mean } \pm \text { SE } \\
\text { SD } \quad .\end{array}$ & $\begin{array}{l}. \\
\therefore \\
\therefore \\
\therefore\end{array}$ & $\frac{9}{9 \cdot 0 \overline{ \pm}} \frac{9 \cdot 7}{2 \cdot 8}$ & $\frac{\frac{4}{6}}{10 \cdot 2 \pm \frac{ \pm}{2 \cdot 5}} 0 \cdot 7$ & $12 \cdot \frac{16}{2 \cdot 4} 0.5$ & $\begin{array}{c}3 \\
7 \\
12 \cdot 7 \underset{5 \cdot 4}{1} \\
y \cdot 4\end{array}$ & $\begin{array}{r}16 \\
33 \\
1\end{array}$ \\
\hline $\begin{array}{l}\text { Subscapular (mm) } \\
\text { Under } 10 \cdot 1 \\
10 \cdot 1-20 \cdot 0 \ldots \\
20 \cdot 1-30 \cdot 0 \ldots \\
\text { Mean } \pm \text { SE } \\
\text { SD } \quad \ldots\end{array}$ & $\begin{array}{l}. . \\
. . \\
. \\
. .\end{array}$ & $\frac{12}{\frac{1}{6 \cdot 6 \pm}} \frac{1}{2 \cdot 5} 0 \cdot 6$ & $\begin{array}{c}5 \\
4 \\
1 \\
11 \cdot 7 \pm \frac{ \pm}{5 \cdot 2}\end{array} 1 \cdot 6$ & 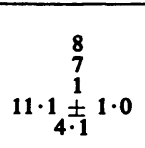 & $\begin{array}{c}4 \\
5 \\
2 \\
13 \cdot 5 \pm 2 \cdot 0 \\
6 \cdot 7\end{array}$ & $\begin{array}{r}29 \\
17 \\
4\end{array}$ \\
\hline $\begin{array}{l}\text { Suprailiac }(\mathrm{mm}) \\
\text { Under } 10 \cdot 1 \\
10 \cdot 1-20 \cdot 0 \ldots \\
20 \cdot 1-30 \cdot 0 \\
\text { Mean } \pm \text { SE } \\
\text { SD } . .\end{array}$ & $\begin{array}{c}. \\
. \\
. \\
.\end{array}$ & $\frac{13}{4 \cdot 2 \overline{ \pm}}$ & $\frac{8}{\frac{2}{7 \cdot 3}} \frac{ \pm 1 \cdot 0}{3 \cdot 1}$ & $\frac{15}{7 \cdot 1 \frac{1}{ \pm} 0 \cdot 6}$ & $\begin{array}{c}9 \\
1 \\
1 \\
8 \cdot 5 \underset{5 \cdot 8}{ \pm} 1 \cdot 7\end{array}$ & $\begin{array}{r}45 \\
4 \\
1\end{array}$ \\
\hline $\begin{array}{l}\text { Biceps }(\mathrm{mm}) \\
\text { Under 10:1 } \\
10 \cdot 1-20 \cdot 0 \quad \ldots \\
20 \cdot 1-30 \cdot 0 \text { SE } \\
\text { Mean } \pm \text { SE } \\
\text { SD }\end{array}$ & $\begin{array}{l}. . \\
. \\
. \\
.\end{array}$ & $5 \cdot 2 \frac{1}{2 \pm 2} 0 \cdot 5$ & $\frac{\frac{10}{6 \cdot 0 \overline{ \pm}}}{2 \cdot 1}$ & $\frac{\frac{16}{7}}{7 \cdot 7 \pm 0 \cdot 3}$ & $\begin{array}{c}7 \\
3 \\
1 \\
7 \cdot 3 \pm 0 \cdot 8 \\
3 \cdot 1\end{array}$ & $\begin{array}{r}45 \\
4 \\
1\end{array}$ \\
\hline $\begin{array}{l}\text { Calf }(\mathrm{mm}) \\
\text { Under } 10 \cdot 1 \\
10 \cdot 1-20 \cdot 0 \ldots \\
20 \cdot 1-30 \cdot 0 . . \\
30 \cdot 1-40 \cdot 0 \\
40 \cdot 1 \text { and over } \\
\text { Mean } \pm \text { SE } \\
\text { SD } \quad . .\end{array}$ & $\begin{array}{c}. . \\
\because \\
. \\
. \\
. \\
.\end{array}$ & $\begin{array}{c}3 \\
6 \\
\frac{4}{15 \cdot 6 \pm} 5 \cdot 8 \\
\frac{5}{5 \cdot 8}\end{array}$ & $\begin{array}{c}-7 \\
3 \\
2 \\
1 \\
25 \cdot 5 \underset{9}{9} 3 \cdot 0\end{array}$ & $\begin{array}{c}-5 \\
8 \\
3 \\
\frac{3}{63 \cdot 3 \pm} 6 \cdot 9\end{array}$ & $\begin{array}{c}\overline{5} \\
1 \\
4 \\
1 \\
26 \cdot 2 \underset{12 \cdot 3}{ \pm} \\
\frac{1}{12}\end{array}$ & $\begin{array}{r}3 \\
20 \\
16 \\
9 \\
2\end{array}$ \\
\hline $\begin{array}{l}\text { Thigh }(\mathrm{mm}) \\
\text { Under } 10 \cdot 1 \\
10 \cdot 1-20 \cdot 0 \\
20 \cdot 1-30 \cdot 0 \\
30 \cdot 1-40 \cdot 0 \\
40 \cdot 1 \text { and over } \\
\text { Mean } \pm \text { SE } \\
\text { SD } . .\end{array}$ & $\begin{array}{l}. . \\
. \\
. \\
\cdots \\
. .\end{array}$ & $\begin{array}{c}4 \\
7 \\
1 \\
\frac{1}{8 \cdot 9} \\
\frac{ \pm}{ \pm \cdot 9} \\
2 \cdot 4\end{array}$ & $\begin{array}{c}\frac{-3}{3} \\
\frac{4}{4} \\
25 \cdot \frac{ \pm}{6 \cdot 4} \\
\frac{ \pm}{4}\end{array}$ & 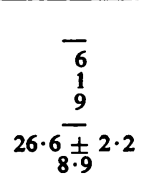 & 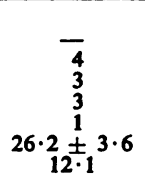 & $\begin{array}{r}4 \\
20 \\
8 \\
17 \\
1\end{array}$ \\
\hline
\end{tabular}

TABLE II

PERCENTILE DISTRIBUTION OF SKINFOLD THICKNESSES

\begin{tabular}{|c|c|c|c|c|c|c|c|c|}
\hline \multirow{2}{*}{\multicolumn{3}{|c|}{ Percentile }} & \multicolumn{2}{|c|}{ Boys } & \multicolumn{2}{|c|}{ Girls } & \multicolumn{2}{|c|}{ Total } \\
\hline & & & Under 10 yr & Over 10 yr & Under 10 yr & Over 10 yr & Observed & Expected* \\
\hline $\begin{array}{l}\text { Triceps } \\
\text { Below the 10th } \\
\text { 10th-50th } \\
\text { 50th-90th } \\
\text { Above the 90th }\end{array}$ & $\begin{array}{l}\ddot{ } \\
\ddot{ } \\
\dot{ }\end{array}$ & $\begin{array}{l}. \cdot \\
\cdots \\
\cdots\end{array}$ & $\begin{array}{l}2 \\
3 \\
6 \\
2\end{array}$ & $\begin{array}{r}\overline{2} \\
8 \\
\end{array}$ & $\overline{11}$ & $\begin{array}{l}-6 \\
4 \\
1\end{array}$ & $\begin{array}{r}2 \\
11 \\
29 \\
8\end{array}$ & $\begin{array}{r}5 \\
20 \\
20 \\
5\end{array}$ \\
\hline \multicolumn{3}{|c|}{$x^{2}=11 \cdot 70$ df $=3$} & $0.01>P$ & .001 & & & & \\
\hline $\begin{array}{l}\text { Subscapular } \\
\text { Below the 10th } \\
\text { 10th-50th } \\
\text { 50th-90th } \\
\text { Above the 90th }\end{array}$ & $\begin{array}{l}\ddot{ } \\
\ddot{*}\end{array}$ & $\begin{array}{l}. . \\
\cdots \\
. . \\
.\end{array}$ & $\begin{array}{l}-3 \\
7 \\
3\end{array}$ & $\begin{array}{c}- \\
55 \\
5\end{array}$ & $\begin{array}{r}- \\
10\end{array}$ & $\begin{array}{l}1 \\
3 \\
5 \\
2\end{array}$ & $\begin{array}{r}1 \\
6 \\
23 \\
20\end{array}$ & $\begin{array}{r}5 \\
20 \\
20 \\
5\end{array}$ \\
\hline
\end{tabular}


or sit unaided, all measurements were taken either with the child supported in the sitting position by a nurse for the first two skinfolds or recumbent on a table padded with foam rubber, to protect any bony kyphos or scar tissue from damage, for the other four skinfolds. In addition, because of muscle wasting the sites of thigh and calf skinfolds were defined as follows:

1. Thigh skinfold: this was measured at the marked mid point between the anterior superior iliac spine and tibiale (on the anterior surface of the thigh);

2. Calf skinfold: this was measured at the marked mid point between tibiale and the medial malleolus (on the medial aspect of the calf).

\section{STANDARDS}

The standards for comparison of skinfolds used here are those of the L.C.C. Survey (1959) by Scott (1961) which provided the basis for the charts produced by Tanner, Whitehouse, and Takaishi (1966) for children aged 5 to 15 years.

\section{RESULTS}

\section{Comparison with Standards (Table II)}

Both triceps and subscapular skinfolds show a significantly different distribution from that shown by the LCC data and differing also from the measurements of Tanner et al., (1966). Although standards on British school children for the other skinfolds are not available as published data, our results indicate that the leg skinfolds of girls and the older boys show a dramatic increase compared to those in the arm. Young boys differ very little from normal in their arm skinfolds. In the remaining three groups, the average skinfold thickness of both calf and thigh, at approximately $25 \mathrm{~mm}$, is about double the triceps value and over three times that of the biceps skinfold.

It seems clear that the increased fat, which is present in the upper limbs and trunk, not only exists in the lower limbs but is present to an even greater extent. Unfortunately, comparison with standards is not possible, but other studies on children and young adults (Brožeck, and Keys, 1951) have shown skinfold thicknesses much lower than those in the children surveyed here.

Pařizkova has shown that skinfold thickness and body fat are closely related. This relationship is represented in Table III and shows the distribution of body fat as a percentage of body weight. The fat content of the three obese groups is over $20 \%$ of body weight when assessed by the sum of five
TABLE III DISTRIBUTION OF FAT AS A PROPORTION OF BODY

(Expressed as \% of body weight calculated from five skinfolds)

\begin{tabular}{|c|c|c|c|c|c|c|c|}
\hline \multirow{2}{*}{$\begin{array}{c}\text { Fat as \% } \\
\text { Total Body } \\
\text { Weight }\end{array}$} & \multicolumn{3}{|c|}{ Boys } & \multicolumn{3}{|c|}{ Girls } & \multirow[b]{2}{*}{ Total } \\
\hline & $\begin{array}{l}\text { Under } \\
10 \text { yr }\end{array}$ & $\begin{array}{l}\text { Over } \\
10 \mathrm{yr}\end{array}$ & All & $\begin{array}{l}\text { Under } \\
10 \mathrm{yr}\end{array}$ & $\begin{array}{l}\text { Over } \\
10 \mathrm{yr}\end{array}$ & All & \\
\hline \begin{tabular}{ll|} 
Under $10 \%$ & $\ldots$ \\
$10-19 \%$ &. \\
$20-29 \%$ &. \\
$30-39 \%$ &. \\
$40 \%$ and & \\
over &..
\end{tabular} & $\begin{array}{r}3 \\
8 \\
2 \\
- \\
-\end{array}$ & $\begin{array}{r}- \\
2 \\
2 \\
-\end{array}$ & $\begin{array}{r}3 \\
14 \\
4 \\
2 \\
-\end{array}$ & $\begin{array}{r}-6 \\
10 \\
- \\
-\end{array}$ & $\begin{array}{l}-6 \\
3 \\
1 \\
1\end{array}$ & $\begin{array}{r}\overline{12} \\
13 \\
1 \\
1\end{array}$ & $\begin{array}{r}3 \\
26 \\
17 \\
3 \\
1\end{array}$ \\
\hline Number $\quad \ldots$ & 13 & 10 & 23 & 16 & 11 & 27 & 50 \\
\hline $\begin{array}{l}\text { Average } \% \\
\text { (5 skinfolds) . . }\end{array}$ & 14 & 21 & 17 & 23 & 23 & 23 & 21 \\
\hline $\begin{array}{l}\text { Average \% } \\
\text { (3 skinfolds) .. }\end{array}$ & 8 & 14 & 11 & 14 & 16 & 15 & 13 \\
\hline
\end{tabular}

skinfolds, whereas using the sum of three skinfolds (used by Parnell's method of somatotyping) markedly lower values are obtained and are shown on the bottom row of Table III.

The pronounced difference in distribution of body fat in spina bifida children is probably connected with their lower limb paralysis since Lee (1959) has described a thickening of subcutaneous tissues in paralysed limbs in chronic hemiplegia. However, skinfold determination measures subcutaneous fat alone and since atrophied muscle becomes partly? replaced by fat the calculation of total body fat will probably underestimate the extent of obesity.

\section{Discussion}

Spina bifida is one of the most serious disabilities from which a child may suffer. Severe as it is, the defect may be worsened by the presence of an additional handicap such as obesity, since any excess weight would impair still further an already grossly reduced mobility.

Although obesity is a disease which tends to become self-perpetuating and highly resistant to treatment at some unpredictable stage of its development, it is also accepted that a child's predisposition to obesity is almost certainly multifactorial (Sheldon, 1970). Among these factors several are particularly likely to affect the spina bifida child simultaneously and continuously. Emotional problems are clearly involved and are important factors in relation to spina bifida, where it may be difficult to decide if any part of the obesity is the result of emotional disturbance or contributory to its cause. A major component is likely to be the psychological trauma associated with the endurance of physical handicaps, immobility, and hospitalization, with the consequential separation of the child from the mother 
(Green, 1939). Mother-child separation has long been recognized as a precipitating factor of 'failure to thrive' but it has not been commonly implicated as a factor in the pathogenesis of childhood obesity (Bakwin and Bakwin, 1940).

Overweight and obesity are not synonymous terms. Obesity refers directly to an excessive accumulation of body fat, whereas 'overweight' provides an inference of fatness. Weight as an indication of fatness is further complicated by the body build consisting of its varying proportions of bone and muscle.

The importance of the early detection of obesity is underlined by the newer concepts of its pathogenesis, for it is believed that there is a critical period during which the lifelong number of fat cells becomes established. Infants and children who become obese may perhaps do so through hyperplasia of adipose tissue cells. In contrast, obesity in adult life may occur through hypertrophy of existing cells, and the greatest difficulty in achieving weight reduction will be met when dealing with patients doubly burdened with an increased number and an increased size of adipose tissue cells. Weight loss in these circumstances can be achieved only by a reduction of the fat content of the excessive numbers of adipose tissue cells to an abnormally low level (Penick and Stunkard, 1970).

Some parents, teachers, and doctors seem to think that childhood obesity does not matter (Asher, 1968). Other doctors adopt an authoritarian role, prescribing dietary restriction with or without appetite suppressants, in which case weight reduction is achieved as long as the doctor-patient relationship is maintained but a better method is required. Medical instruction and jargon is often misinterpreted (Tring and Hayes-Allen, 1973) and it appears to be fairly common for patients not to understand what was said to them by their medical advisers. It is also probable, as Freeston (1971) suggests, that a need exists for a special visitor to call on these patients at home. The parents of spina bifida children require a person capable of explaining various complications which might arise in their child and of discussing ways of overcoming them.

\section{SUMMARY}

Obesity among children with spina bifida has been confirmed. Its true extent, however, can be easily overlooked if conventional methods are used for its measurement. The distribution of body fat among spina bifida children differs significantly from all available standards, the greatest increase apparently occurring in the lower limbs. Because obesity is largely an avoidable condition its presence is unfortunate because it can still further impair an already seriously reduced mobility.

\section{REFERENCES}

Asher, P. (1968). Child health problems in the community. Nurs. Times, 64, 963.

Bakwin, H., and BaKwin, R. M. (1940). Growth, development and care of the child. Amer. J. Dis. Child., 59, 112.

British Medical Journal (1970), 2, 64.

BRožEK, J., and KEYS, A. (1951). The evaluation of leanness-fatness in man: norms and interrelationships. Brit. J. Nutr., 5, 194.

EID, E. E. (1970). Follow-up study of physical growth of children who had excessive weight gain in first six months of life. Brit. med. J., 2, 74.

Freeston, B. M. (1971). An enquiry into the effect of a spina bifida child upon family life. Develop. Med. Child Neurol., 13, 456.

GREEN, R. (1939). Inter-agency use of child guidance clinics from the point of view of the cooperative effort of social workers. Amer. J. Orthopsychiat., 9, 170.

HAYes-AlleN, M. C. (1972). Obesity and short stature in children with myelomeningocele. Develop. Med. Child Neurol., 14, Suppl. 27, p. 59.

Hooper, P. D., and AleXander, E. L. (1971). Infant morbidity and obesity. A survey of 151 infants from general practice. Practitioner, 207, 221.

Illingworth, R. S. (1968). The Normal Child, 4th ed. Churchill, London.

LEE, M. M. C. (1959). Thickening of the subcutaneous tissues in paralyzed limbs in chronic hemiplegia. Hum. Biol., 31, 187.

Lloyd, J. K., WolfF, O. H., and Whelan, W. S. (1961). Childhood obesity. A long-term study of height and weight. Brit. med. J., 2, 145.

Lorber, J. (1969). Spina bifida. Practitioner, 202, 522.

Newens, E. M., and Goldstein, H. (1972). Height, weight, and the assessment of obesity in children. Brit. J. prev. soc. Med., 26, 33.

Paǩízkova, J. (1961). Total body fat and skinfold thickness in children. Metabolism, 10, 794.

—, and BŮžKovÁ, P. (1971). Relationship between skinfold thickness measured by Harpenden caliper and densitometric analysis of total body fat in men. Hum. Biol., 43, 16.

Parnell, R. W. (1958). Behaviour and Physique. Arnold, London.

Penick, S. B., and Stunkard, A. J. (1970). Newer concepts of obesity. Med. Clin. N. Amer., 54, 745.

Scotr, J. A. (1961). Report on the Heights and Weights (and other measurements) of School Pupils in the County of London in 1959. L.C.C., London. 
SEDGwiCK, J. P. (1971). Obesity-the health hazard of our time. S. Afr. med. J., 45, 362.

SHELDON, J. (1970). Obesity: some current views regarding its aetiology. Postgrad. med. J., 46, 613. (October).

Tanner, J. M., HiernauX, J., and Jarman, S. (1969). Growth and physique studies. In Human Biology: A Guide to Field Methods. International Biological Programme Handbook No. 9. Blackwell, Oxford. Standards from birth to maturity for height, weight, height velocity, weight velocity: British children 1965. Arch. Dis. Childh., 41, 454.

Tracey, V. V., De, N. C., and Harper, J. R. (1971). Brit. med. J., 1, 16.

Tring, F. C., and HaYes-Allen, M. C. (1973). Understanding and misunderstanding of some medical terms. Brit. J. med. Educ., 7, 53.

.

